\title{
Kako živeti skupaj?
}

Živeti skupaj pomeni marsikaj. Ob vprasanju, kako živeti skupaj, se utrne razmislek o večkulturni skupnosti, misli adtavajo $k$ stari dami Evropi, ki ne zmore poravnati svojih krinolin ... aktualne teme o prihodnosti, $v$ kateri se bomo morali znati prilagoditi spreminjajočim se naravnim okolišcinam in zapletenim kulturnim okoliščinam. Toda živeti skupaj ne pomeni le druženja velikih skupin ljudi, marginalnih in vladajočih; pomeni tudi moškega in žensko, pomeni Žensko, moškega in otroka, starejšega in mlajšega. Občutenje za skupaj raste iz primarne skupine ljudi, iz njihovih odnosov in ne iz romantičnega tarnanja ali iz političnega zanosa.

$V$ sodobnih razmišljanjih o načinih oblikovanja skupnosti najdemo dve nasprotni miselni shemi kot instrumenta opazovanja in interpretiranja. Na eni strani daljice so tisti avtorji, ki vidijo človeka kot individualista in potrošnika, ki o svojem življenju razmišlja brez zgodovinske vpetosti. Človek začne svoje življenje z rojstvom in konča s smrtjo. Vse se zgodi med točkama $R$ in $S$. Pred točko $R$ in za točko $S$ ni ničesar. Drugi koncept je koncept smisla, ali kot zapiše Buber, eksistenca ne pomeni bivati »zase", biti zavit v svojo subjektivnost, temveč pomeni bivati iz oči $v$ oči z drugim, kjer se razvije odnos jaz-ti in tvoja, njegova, vajina zgodba.

\section{ODNOSI NAS VZGAJAJO}

Je lažje jemati ali dajati? Je lă̌je biti preganjalec ali žrtev? Bi raje billi kladivo ali žebelj? Najtežja je izmenjava, kjer ni nihče kladivo in nihče žebelj, kjer dva ali več ljudi razvijejo dialog, kjer ni politične demokracije z večino, ki zmaguje, temveč je usmiljenje in sočutje, ljubezen in dobrota ... kot v družinski skupnosti. In takoj se vzpne žugajoči kazaleo in vprašanje: ali ni v družini nasilje največje, ali ni v družini zlorabljanja otrok? Ali ni v družini neznosnega spodbujanja tekmovalnosti, da otrok ne zmore več? Je, vendar ne v vseh. Po patoloških stanjih še ne moremo zaključiti, da je nekaj slabo in da ni več prinerno. Vsak pojav se srečuje s svojo senčno platjo, vsak s svojo patologijo, ima svoj jin in jan, Kako ne bi družina imela svoje patologije! Škoda bi bilo, če zaradi temne strani ne bi opazili svetle, ali celo, da bi zaradi temne strani zanikali svetlo in pristali na pesimizem in svetobolje.

Na eni strani se kažejo zlorabe kot oguljena kolena, ki pokukajo skozi raztrgane nogavice, na drugi strani se pokaže velika potreba ljudi po ljubezni v času osamljenosti. Kot obliž na ranjeno dušo. Kako smo pripravljeni na to? Kako sprejemamo ženske in moške v njilhovih in svojih novih načinih vedenja: monogamija ali poligamija? Poligamija na način zaporednih monogamij? Mar iščoč vsebino zamenjujemo le obliko?

Kaj storiti, da bodo rodile ženske, ki bi rade rodile? (Kako suhoparno zveni vprašanje, kako povečati nataliteto!) Zakaj mladi nimajo otrok? Je svet res tako neprijeten, da si vanj ne želijo rojevati otrok? Ali pa so ženske diskriminirane na delu, ker se jim lahko "zgodi $\propto$, da rodijo. Ne gre za to, da bi morale rojevati, temveč za to, da bi lahko rojevale.

Odnosi $v$ družini se razvijejo drugače kot 
politična demokracija, kjer štejejo glasovi, predstavniki različnih interesov, in večina premaga manjšino. Družinska skupnost deluje tako, da so vsi člani spoštovani, da upoštevajo izkušnje, znanje (vsebine in veščine) vseh, čustva vseh. Ko se zavemo, da nas medsebojni odnosi $v$ svoji dinamiki oblikujejo in vzgajajo, presenetljivo hitro odkrijemo kreativen način, kako se spopadati z neprijetnimi situacijami, kako nekatere sprejeti, druge spremeniti, kako v nekaterih ostati in iz drugih oditi. Ugotovimo, da nas prijetni in neprijetni odnosi vzgajajo. Da imajo tudi konflikti, žalost, jeza svojo vlogo pri našem osebnostnem zorenju in pri pisanju družinskih zgodb. Tedaj razvijemo svojo novo plast pomenov in interpretacije dogodkov.

\section{ŽIVETI V DRUŽINI: ISKRENOST ODNOSA}

Znašli smo se v slepi ulict, slišsi se vprašanje, kako naprej. Želimo si ljubezni, pa je ne znamo živeti. Poplava priročnikov o srečnem življenju v dvoje samo še izostri problem nezmožnosti skupnega življenja v temeljnem odnosu združitve dveh sistemov narave in dveh sistemov kulture: moškega in ženske. Družina nam daje možnost, da navežemo in oblikujemo bistveni odnos jaz-ti: ko na drugega ne gledaš kot na predmet svojega opazovanja in uporabe, ko je drugi človek predmet razmišljanja, uporabe, včasih lahko tudi skrbi in podpiranja, je pa še vedno zgolj predmet. Ko ljudje živijo v čustveni zlorabi, se - z Bubrovimi besedami - razvije odnos jazono in tedaj je tudi jaz drugačen, kot bi bil v odnosu jaz-ti.

Cloveško bivanje gradita oba odnosa, jaz-ti in jaz-ono, toda vprašanje je, kateri odnos bo $v$ naši družini glavni arhitekt in kateri le njegov pomočnik. Za družine je bistveno, da graditelj ostaja odnos jaz-ti, kajti če bi ga želeli imeti le kot pomočnika, bo začel izginjati.
Razmerja, ko drugega človeka uporabljamo, so pridobila na pomenu, ki jim ga pripisuje kultura, kjer z ljudmi upravljamo in kjer so ljudje človeški kapital. Sicer res kot vrsta človeški, ampak samo kapital, za katerega vemo, da ga vodi načelo dobička. Napihnila so se ta uporabljajoča razmerja in oblikujejo jaz, ki ima vse, zna ravnati z usem, lahko vse kupi, toda nezmožen je iskati ti in zato sprašuje: kako naj živim, ko inam vse in nimam ničesar: Primež zahodne potrošniške miselnosti se privija in človeku megli okno, ki mu kaže interpersonalnost, odnose, preko katerih se vzpostavi kot človek. Ali je res človek usmerjen v svet stvari in so mu tudi ljudje le stvari, ki si jih prilašča? Ali bomo odnose jaz-ti iskali kot srajco srečnega cloveka iz slovenske ljudske pravljice?

Mogoče pa je novoletni čas tisti, ko lahko v družini začnemo graditi odnose jaz-ti.

Srečno!

Nives Ličen

Buber, M. (2004), Božji mrk. Celje: Mohorjeva diužba. Buber, M. (1999). Dialoski princip. Ljubljana: Drustivo 2000.

Houellebecq, M. (2003). Osnowni delci: Cankurjeva založba.

Verhaeghe, P. (2002). Ljubezen v času osamljenost. Trije eseji o gonu in žclji. Ljubljana: Orbis. 